\title{
Role of Plasmids in Microbiology
}

\section{Husne Banu and Kurcheti Pani Prasad*}

ICAR-Central Institute of Fisheries Education, Panch Marg, off Yari Road, Versova, Mumbai, Maharashtra, India

\begin{abstract}
Plasmids are not integral part of bacteria as their absence makes no harm. But the extraordinary properties carried by plasmids make them attractive to study their usefulness for microbes in a hostile environment and it has tremendous contribution for molecular biotechnology. There are many classification of plasmids based on their properties, compatibility or replication pattern but still many unidentified useful plasmids are remain. Two properties of bacteria namely antibiotic resistance and bioremediation have come from plasmids. Probably there are many researches on antibiotic resistance group of bacteria which transfer their determinants through R-Plasmids. These resistant plasmids are used for selective growth of positive clones in gene cloning experiments. But transfer of these plasmids, are quite harmful for aquatic animals as well as for human being, as it increases the antibiotic / therapeutics dose resistance. Microbes are ultimate stage of food chain where everything on earth has to be recycled. Based on this concept researchers have identified a process called Bioremediation, where a group of useful plasmids diversify bacteria to tolerate high concentration of pollutants and to degrade it. With the increase in human population, pollution is a big challenge. So the study of plasmids having crucial role in bioremediation will definitely have vast scope in future. Other properties such as nitrogen fixation, sulphur utilization and hydrocarbon degradation need to be studied in details for their implementation for mankind or to address various environmental issues.
\end{abstract}

Keywords: Plasmid; Aquaculture; Gene transfer; Heavy metal; Antibiotic residue; Antibiotic resistance

\section{Introduction}

\section{Importance of bacterial genomic diversity}

The dynamics of bacterial genome has aroused from a long series of evolutionary events. These evolutionary events are responsible for unique set of biological function in large number of bacteria. Bacteria have two separate genetic systems such as chromosomal DNA and extra-chromosomal DNA. Both genetic systems can undergo gene transfer by various means which accelerates process of evolution in bacterial community. Genetic diversity led by evolution is main cause of bacterial adoptability to vast range of conditions. Bacteria are present everywhere even at extreme conditions such as high salinity, extremely high and low temperature where no higher animal will survive. They have different phenotypic characters along with diverse metabolic activity. There are many processes involved in bacterial genomic diversity such as mutation, recombination and Horizontal gene transfer. Mutations are natural alteration during DNA replication or it may occur due to a mutagen. Recombination most commonly takes place between closely related bacterial strains and its frequency decreases with decreasing sequence similarity between the donor and recipient. While mutation brings variation in existing genome, recombination serves alteration within a species. But both of them has little contribution for microbial evolution in comparison to the horizontal gene transfer which alters the genes across the species boundaries [1-3]. There are three process of horizontal gene transfer mechanism such as conjugation, transformation and transduction. The frequency at which gene transfer occur in aquatic ecosystem is not known. Each one has different probabilities to occur in various conditions like availability of external DNA and presence of favorable environmental conditions (nutrient composition, cell density, temperature and salinity) but they have a common means of gene transfer that is through Plasmid.

\section{Role of plasmid in gene transfer}

Extra-chromosomal DNA is highly folded circular selfreplicating independent body found in most bacteria. Necessary genetic information are stored in chromosomal DNA whereas other additional characteristic such as UVC resistance, catabolism of unusual carbon sources, resistance to antibiotics, heavy metals and pesticides, degradation of complex organic matter are coded in plasmids [4]. This is why plasmids are regarded as accessory genetic element to bacterial chromosome. Genetic diversity in bacteria is due to the active transport of genes which are incorporated with accessory elements like plasmids. These plasmids survive in host by vertical transmission and adapt to new conditions by horizontal gene transfer. Horizontal gene transfer through plasmids has received much attention due to the incidence of antibiotic resistance of certain pathogenic bacteria. The plasmids carrying resistance gene are supposed to transfer those genes to other bacteria and helps in spreading the resistance. This kind of plasmid transformation in aquatic ecosystem has potential impact on human health. There are applications of bacterial transformation which carry and spread plasmid having xenobiotic degradation genes. These can be used for bioremediation of heavy metals and toxic chemicals.

This paper is a review on activity of plasmid in aquatic microbes. It covers the description regarding their types, distribution in aquatic environment, transportation mechanism and various properties.

\section{Types of plasmids and their function}

Plasmids are commonly found in variable amounts in bacteria isolated from various aquatic environments, with frequencies of plasmid incidence reported at $23 \%$ to $46 \%$ [5-7]. Plasmids are classified

${ }^{*}$ Corresponding author: Kurcheti Pani Prasad, Principal Scientist, ICAR-Central Institute of Fisheries Education, Panch Marg, off Yari Road, Versova, Mumbai-400061, Maharashtra, India, Tel: +91 9867241101; E-mail: kpaniprasad@cife.edu.in

Received December 16, 2016; Accepted February 08, 2017; Published February 10, 2017

Citation: Banu H, Prasad KP (2017) Role of Plasmids in Microbiology. J Aquac Res Development 8: 466. doi: 10.4172/2155-9546.1000466

Copyright: ( $) 2017$ Banu H, et al. This is an open-access article distributed under the terms of the Creative Commons Attribution License, which permits unrestricted use, distribution, and reproduction in any medium, provided the original author and source are credited. 


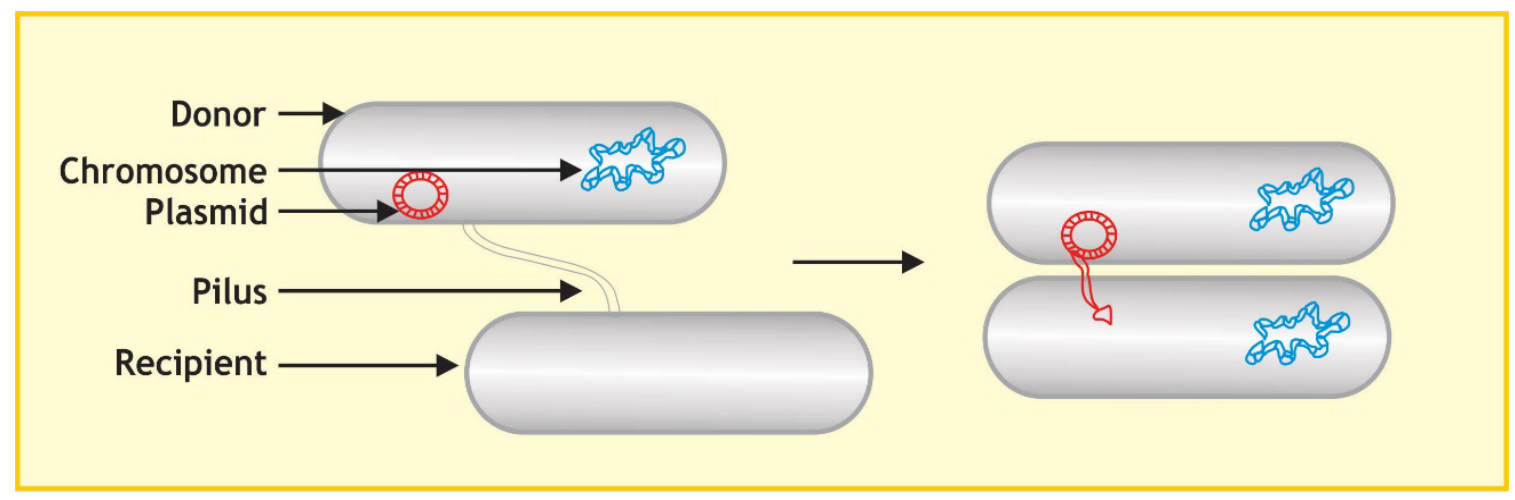

Figure 1: Transfer of plasmid between bacteria by conjugation.

depending on their different function in a host. Depending on their replication property, broadly, they can be classified as compatibility and incompatibility groups. When two different plasmids can coexist stably in a cell, then they are called compatibility plasmid. In opposite, when two plasmids with similar replicon or replication elements are unable to coexist, then it is known as incompatibility of plasmids. It was first described for the F plasmid in the early 1960s. Classification based on this property of plasmid was developed in the early 1970s [811]. At present, about 30 incompatibility groups are recognized among plasmids of enteric bacteria and 7 are recognized among staphylococcal plasmids [12]. It is most common method of plasmid classification but it has a limitation that it does not consider plasmids with high homology and different replication control genes. Depending on their property plasmids are classified as F plasmids, colicinogenic (Col) plasmids and R plasmids [13].

F-plasmid: F (fertility) factor of Escherchia coli K-12 was the first plasmid to be described. Lederberg et al. and Hayes reported the occurrence of a peculiar infective inheritance mediated by an agent called $\mathrm{F}$ which controls system of sex compatibility in E. coli K-12 strain $[14,15]$. Original K-12 strain and most of its descendants show no mating limitations, but a few derivative strains have more recently been found which are not crossing with one another. These crossincompatible strains are called $\mathrm{F}^{-}$, while strains showing the normal, apparently homothallic condition have been termed as $\mathrm{F}^{+}$.

Col plasmid: These are group of small multicopy colicinogenic plasmids which encode the genes to synthesize colicins (bacteriocins). These plasmids need DNA polymerase I for replication and are amplified by chloramphenicol with the exception of ColE2. The Col plasmid groups such as CoL4, ColD, ColK, and ColEl share a number of replication characteristics. Zverev et al. has reported that ColA, ColD, and ColK each contain DNA sequences homologous to the region of ColEl which is involved in autonomous replication [16]. These plasmids are widely used in gene cloning process. They are also used as a good model for gene replication, transcription and translation.

R-plasmid: During 1980s most of the Shigella flexneri bacterium found in Korea were resistant to many drugs and it was of high human health concern. Some of the strains were showing multiple resistant to the six drugs like chloramphenicol $(\mathrm{Cm})$, tetracycline $(\mathrm{Tc})$, streptomycin $(\mathrm{Sm})$, sulfisomidine $(\mathrm{Su})$, ampicillin (Ap) and trimethoprim (Tp). This resistant property was co-transferred to E. coli by conjugation, indicating that the resistance was $\mathrm{R}$ plasmid-mediated. Most of them belong to incompatibility group of plasmids (Inc FIl \& Inc B) [17].

Suicide plasmids: These are plasmids which get transferred to another bacterial cell but do not replicate further and are also known as mobilizable plasmids. These plasmids are mostly used for transposon and gene replacement experiment. Most of the suicidal/mobilizable plasmids are based on broad host range plasmids R388 plasmid (IncW) and RP4 plasmid (IncPa) [18] but there is more advantage if it is based on small narrow host range plasmids.

Virulence plasmids: Presence of these plasmids increases pathogenicity of microbes. There is an excellent review on virulent plasmids of E. coli by Johnson et al. [19]. Some of them are highly stable where others are unstable. Most of them has originated from a single strain and diversified by accumulating traits which is necessary for respective virulence. There are different types of $E$. coli virulence plasmids exist, including those essential for the virulence of enterotoxigenic E. coli, enteroinvasive E. coli, enteropathogenic E. coli, enterohemorrhagic $E$. coli, enteroaggregative $E$. coli, and extraintestinal pathogenic E. coli.

\section{Mode of plasmid transfer}

The genetic information encoded in a self-replicating extrachromosomal DNA (plasmid) of bacteria is transferred across a broad range of microorganism through conjugation, transformation and transduction. In case of conjugation the donor cell must have a conjugative plasmid and establish a strong physical contact with the recipient cell. In contrast later two methods do not require any physical contact with in donor and recipient.

Conjugation: This requires cell to cell contact of donor and recipient cells and DNA metabolism of donor cell. It is postulated that conjugation is a twostep process. In first step, the DNA that is covalently linked to recipient is initially transported in a passive manner, trailing on the relaxase where pilus helps in transporting DNA across several membrane barriers in recipient cell and second step is active pumping of the DNA to the recipient, using the already available T4SS transport conduit [20]. There are reports of inter-kingdom genetic exchange by conjugation. Heinemann and Sprague has reported that transfer function encoded by two plasmids such as R751 and F (fertility factor) and two mob/oriT system are able to transfer DNA from bacteria to yeast by conjugation process [21]. Even there are reports of conjugative transfer between Escherichia coli, the RK2 plasmid system and Chinese hamster ovary CHO K1 cells [22]. Conjugative plasmid, such as RP4 has extremely broad host range and these plasmids contribute a lot to genetic diversity. There is much information regarding gene transfer by conjugative mechanism in aquatic ecosystem. Sengelov and Sørensen have selected donor and recipient bacteria in lake water microcosm that received plasmid RP4 by conjugation on filters [23]. Research in marine ecosystem with a detection system for gene transfer based on the 


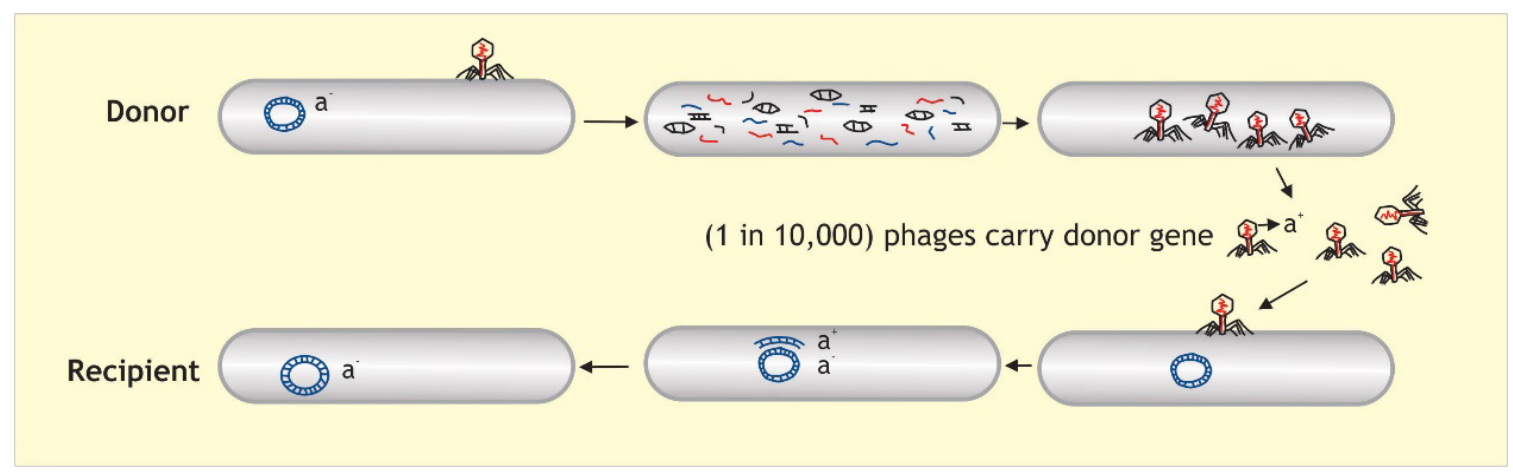

Figure 2: Gene transfer through transduction occur between bacteriophages and bacteria.

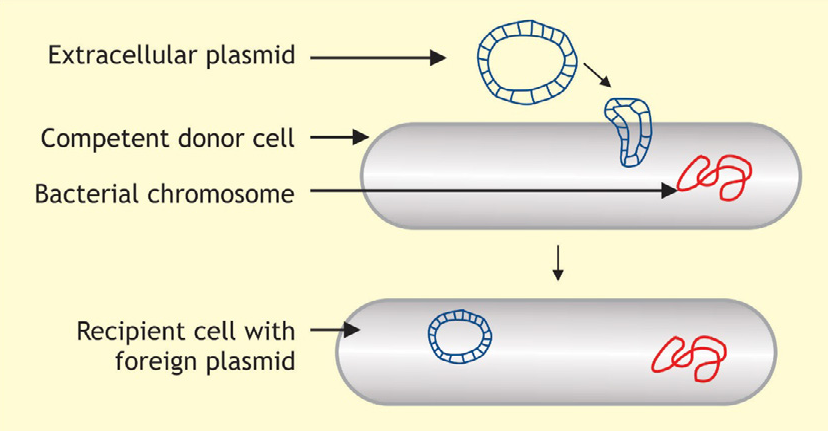

Figure 3: Extracellular plasmids are transferred to competent cells by the process of transformation.

green fluorescent protein (GFP) has shown that conjugative plasmid pBF1 from Pseudomonas putida to indigenous bacteria in seawater (Figure 1) [24].

Transduction: It represents plasmid mediated gene transfer in bacterial community through the bacteriophages which are viruses infecting bacteria. It can be generalized transduction (ability of transducing any gene into bacterial chromosome) or specialized transduction (it can transduce a particular genes). Jiang and Paul has done a transduction related experiment using marine water bacterial isolates, group of bacterial community as recipient of Plasmid pQSR50 and marine phase host isolates [25]. The results revealed that transduction frequency were $1.333 \times 10^{-7}$ to $5.133 \times 10^{-9} /$ plaque forming unit (PFU) in bacterial isolates group, $1.583 \times 10^{-8}$ to $3.73 \times 10^{-8} / \mathrm{PFU}^{\prime}$ in bacterial community and overall $1.33 \times 10^{14}$ transduction events per year occur in the Tampa Bay Estuary. Transduction in freshwater ecosystem is reported in $P$. aeruginosa streptomycin resistance by a generalized transducing phage, F116, in an experiment conducted with a flow-through environmental test chamber for 10 days period. Mean transduction frequencies ranged from $1.4 \times 10^{-5}$ to $8.3 \times 10^{-2}$ transductions per recipient [26]. A pseudo-lysogenic, generalized transducing bacteriophage, UT1, isolated from a natural freshwater habitat, is capable of mediating the transfer of both chromosomal and plasmid DNA between strains of $P$. aeruginosa (Figure 2) [27]

Transformation: It is the most common method of bacterial gene transfer in nature. The process requires competent cells which is ready to accept extracellular plasmid and further stable replication inside recipient cells. Artificial transformation by preparing competent E. coli bacterial cells in lab is a common and widely used method in gene cloning. But there are many naturally occurring competent bacteria which participate in natural transformation like Streptococcus pneumoniae and Neisseria gonorrhoeae (Figure 3) [28,29].

\section{Plasmids distribution in aquatic environment}

Eventhough DNases are ubiquitous in the environment, because there may be $>90 \%$ DNase producing bacteria in aquatic and soil environment [30,31]. extracellular plasmid is found everywhere. Gene transfer via plasmids may occur through extracellular environmental DNA. Natural plasmid transformation is a means of plasmid acquisition by aquatic bacterial population. Plasmids are released to environment through both abiotic (e.g., ionic strength, $\mathrm{pH}$, temperature [32] and biotic factors [33]. Bacteriophage infection and predation by protozoa are probably the main biotic factors of the presence of extracellular DNA in the aquatic environment $[34,35]$. The persistency of free plasmid in soil has been evaluated by Romanowski et al. [36] in an experiment period of 60 days with plasmid pUC8-ISP DNA introduced into 10-g samples of various soils and kept at $23^{\circ} \mathrm{C}$. The data concludes that halflife period of plasmid varies in different type of soils from 9.1 to 28.2 and persist for a long period enough to be available for uptake by natural competent cells. Later studies by him through PCR and electroporation conformed that transforming activity was found up to 60 days after inoculation of the soils [37]. Plasmid transformation mostly in marine environment has extensively studied by many authors [38-41]. Stewart and Sinigalliano has demonstrated the first marine model for natural transformation in P. stutzeri by Zo-Bell [41].

The transformation was detected by ajauni plate method and frequency detected by filter transformation process. It is concluded that transformation by cell contact is 10 -fold lesser that purified DNA. But first proof of plasmid transformation in natural water body was given by Paul et al. [42]. It has been reported that in water column, transformation frequencies ranged from $1.7 \times 10^{-6}$ to $2.7 \times 10^{-10}$ transformants per recipient, with highest frequencies occurring when low levels of nutrients (peptone and yeast extract) were added. The 


\begin{tabular}{|c|c|c|}
\hline Heavy metal & Bacterial - plasmid & References \\
\hline \multirow{3}{*}{ Mercury } & E coli- pDU1358 & Ji and Silver, 1995 [59]; \\
\hline & S aureus- pl258 & \multirow{2}{*}{ Johnson et al. 1991[60] } \\
\hline & $P$ aeruginosa- pAO1161 and PA103 & \\
\hline \multirow{2}{*}{ Arsenic } & E. coli- R773 & \multirow{2}{*}{ Ji and Silver, 1995 [59] } \\
\hline & S. aureus- pl258 & \\
\hline \multirow{3}{*}{ Copper } & E. coli- pRJ1004 & Lee et al. 1994 [51]; \\
\hline & P. syringae pv. Tomato- $\mathrm{pPT} 23 \mathrm{D}$ & \multirow{2}{*}{ Cooksey, 1994 [50] } \\
\hline & P. syringae- pPSI1 & \\
\hline \multirow{2}{*}{ Cadmium } & S. aureus- pl258 & Nucifora et al. 1989 [52]; \\
\hline & Listeria monocytogenes-pLm74 & Lebrun et al. 1994 [61] \\
\hline \multirow{2}{*}{ Chromate } & P. flurescence- pLHB1 & Ohtake et al. 1987 [62] \\
\hline & P. aeruginosa- pMG6 & Summers and Jacoby, 1978 [63] \\
\hline \multirow{2}{*}{ Tellurite } & \multirow{2}{*}{$\begin{array}{l}\text { K. aerogenes- IncHII, pHH1508a, } \\
\text { E. coli- RP4Ter, pHH1508a }\end{array}$} & Walter et al. 1989 [64]; \\
\hline & & Taylor et al. 1988 [65] \\
\hline Silver & E. coli- pMG 101 & Silver, 1996 [47] \\
\hline
\end{tabular}

Table 1: Heavy metal resistant plasmid.

result of transformation frequency in sediments is comparatively less to marine water. It is experimentally proved that $45 \%$ of Vibrio genera contained 1-3 plasmids [43]. The high-frequency-of-transformation (HFT) estuarine Vibrio strains (D1-9) were transformable with the broad host range plasmids with frequencies ranging from $1.1 \times 10^{-8}$ to $1.3 \times 1 \mathrm{O}^{-4}$ transformants per recipient with plasmid DNA [24]. Transformants can be easily verified by colony hybridization with probes for the transforming DNA. The evidence of gene transformation in natural fresh water body has come late and most of the natural transformation related work is done with marine water bacteria. $E$ coli found in natural ecosystem under goes natural competency development which is a method of plasmid transformation [44]. The natural transformation in freshwater is influenced by temperature fluctuation but do not depends on high temperature. It may also occur at low concentration of Calcium ion (1-2 mM).

\section{Properties of plasmid}

Heavy metal tolerance: Microbial method for heavy metal detoxification is widely used due to its high specificity for target heavy metal where as other alternatives are not so specific in action. Plasmid mediated heavy metal tolerance is well studied as this phenomena is older than antibiotic resistance of bacteria. General mechanisms involved in such kind of tolerance are enzymatic alteration of the toxic compound, enzymatic modification of the target site, development of alternate metabolic pathways, and extrusion of the toxic compound from the cell [45]. Studies related to toxic metal ion tolerant bacteria increased rapidly after the discovery of mercury-resistant bacteria which can volatilize mercury [46]. Apart from mercury there are other highly specific metal tolerance systems such as arsenic, copper, cadmium, zinc, cobalt, nickel, tellurite, silver and other toxic metal ions [47]. Each bacteria has different mode of detoxification. But most of them involve a group of genes that is known as operon system. An example of such kind of well-studied operon is mer operon for mercury resistant bacteria. This operon is well studied both in Gram+ and Gram- bacteria. It consists of series of genes such as merR, merA, merB and mer $\mathrm{D}$ whose product are engaged in breaking of mercury-carbon bond, intracellular detoxification and transport of toxic chemical across the cell membrane. This system slightly varies in gram+ and Gram- bacteria due to the expression pattern of merR which encodes regulator protein that controls polymerase activity. Second most studied heavy metal tolerance is Arsenic operon system. There are five different types of operon and among them plasmid R773 is extensively studied which consists of genes such as ArsA, ArsB, ArsC, ArsD and ArsR. ArsC gene is involved in Arsenate reduction whereas ArsA, ArsB are involved in ATP dependent membrane transport of toxic arsenite and ArsR is a regulatory gene. In 1983 Tetaz and Luke reported a copper tolerant E. coli strain found in effluent of a piggery where the pig was fed with copper sulfate supplemented feed [48]. The resistance was due to a 78-megadalton plasmid designated as pRJ1004. Latter it was experimentally proved that there is an operon of genes named as pcoABCD which is followed by two regulatory genes, pcoR and pcoS. The pcoA, pcoC are two periplasmic proteins and $\mathrm{pcoB}, \mathrm{pcoD}$ are outer and inner membrane proteins respectively. All together helps in reducing intracellular copper concentration and efflux of toxic copper outside the cell. Copper is also used as antimicrobial compound against plant disease. A copper resistant plasmid (pPT23D) present in PT23 strain of P. syringae [49]. Apart from this a 35-kilobase plasmid was conserved among 12 copper-resistant strains of $P$. syringae pv. Tomato [49]. There is other similar copper resistance mechanism found in Pseudomonas [50] Xanthomonas [51]. There are reports of other metal resistant bacteria controlled by plasmids such as Cadmium and Chromate and tellurite etc. (Table 1). Resistance to $\mathrm{Cd}^{2+}$ is common in Staphylococcus aureus with two resistant determinants (cadA and cadB) carried by plasmid p1258. Among these determinants $c a d A$ helps in energy-dependent efflux from cell whereas $c a d B$ codes for a metal binding protein [52]. The hexavalent chromium compounds are highly toxic to fish $\left(\mathrm{LC}_{50} 39.40 \mathrm{mg} / \mathrm{l}\right.$ for $\left.\mathrm{Cr}^{+6}\right)$ and affect normal respiration [53]. Some of the bacteria are able to reduce chromate to non-toxic forms and these can be used for bioremediation. Chromate-resistant strain of $P$. mendocina MCM B-180 which carries a plasmid, pARI180 is really able to transfer chromate reduction property to other competent bacteria [54]. Even P. fluorescens strain LB300 depends exclusively on plasmid pLHB1 for Chromate resistance because loss of plasmid results simultaneous loss of resistance [55]. Silver nanoparticles are extensively used as biocides, preservatives and in medical devices. There is huge application of silver nanoparticles but excessive use lead to bioaccumulation in aquatic ecosystem. Silver nitrite is highly toxic chemical and particular to larval or newly hatched fish complete mortality occurs at $1.3 \mu \mathrm{g} / \mathrm{L}$ and significant reduction in fish survival at $0.5 \mu \mathrm{g} / \mathrm{L}$ silver [56]. But silver resistant Salmonella typhimurium which carries Plasmid pMG101 is highly pathogenic [57]. Few bacteria as Alcaligenes eutrophus carry multiple metal resistance $\left(\mathrm{Cd}^{++}, \mathrm{Co}^{++}\right.$, $\mathrm{Cr}_{4}{ }^{=}, \mathrm{Cu}^{++}, \mathrm{Hg}^{++}, \mathrm{Ni}^{++}, \mathrm{Pb}^{++}$and $\mathrm{Zn}^{++}$) plasmids such as pMOL28 and pMOL30 (Table 1) [58]. 
Nitrogen fixation: Nitrogen fixing prokaryotic organism are unique for having $\mathrm{N}_{2}$ fixing ability as well as most of them (Blue green algae) are autotrophs [59-64]. Nitrogen fixing genes are conserved in chromosomal DNA and plasmids. Cyanobacteria are widely distributed and diverse group of autonomous bacteria which mostly carry single or multiple phenotypically cryptic plasmids. Molecular study of Cyanobacteria strains shows that it contains several plasmids [65]. Analysis of unicellular Cynobacteria Synechococcus strains has revealed to carry homologous plasmids. Even genetically distinct group of strains carry identical plasmids which may be due to intergeneric or interspecies transmission of plasmids in nature [66]. But most of their function is still unknown. The symbiotic bacterium of genus Rhizobium carries high molecular weight plasmids $\left(90-350 \times 10^{6}\right)$. In R. leguminosarum plasmids has great role in nodule formation and helps in symbiosis. It carries nitrogen fixation (nif) genes [67]. There are also reports regarding presence of nif genes in prokaryotes like Klebsiella pneumoniae, P. stutzeri and group of cyanobacteria. The DNA hybridization of Klebsiella with other bacteria demonstrates that there is a high homology of nif genes between interspecies bacteria [68]. Most of the nif genes are encoded by chromosomal DNA but hybridization of plasmids isolated from Rhizobiwn Zegwninosarum with cloned nif gene of Klebsiella reveals that at least few nif genes are located in plasmids [69]. The interspecific transfer of nitrogen-fixing ability (Nif) from strains of $R$. trifolii containing $\mathrm{P} 1$ group $\mathrm{R}$ plasmids to other bacterium explains about plasmid mediated transfer of this gene. Bishop et al. has reported an intergeneric transformation between Nif mutant of Azotobacter vinelandii and $R$. trifolii which may be due to the whole plasmid transformation [70]. Other plasmid related experiments shows that certain hybrid nif plasmids drastically inhibit the expression of the chromosomal nif genes of K. pneumonia [71]. The inhibition is due to polypeptides made by plasmid which interferes with Nif expression or it is due to the inhibitory plasmid DNA which interacts directly with a macromolecule in the cell and inhibits nif gene expression. Masterson et al. has reported about the presence of structural nif gene on large plasmids of all fast-growing R. japonicum but slow growing strains do not have nif gene on their plasmid [72].

\section{Sulfur utilization}

There are a group of bacteria known as sulfur utilizing bacteria which metabolize sulfur and this activity is useful for sulfur cycling in nature. Most of sulfur compounds are oxidized by Archaea and Bacteria. These compounds are used as electron donors for anaerobic phototrophic and aerobic chemotrophic growth, and are mostly oxidized to sulfate. The common energy sources for such bacteria are hydrogen sulfide $\left(\mathrm{H}_{2} \mathrm{~S}\right)$, sulfur and thiosulfate $\left(\mathrm{S}_{2} \mathrm{O}_{3}{ }^{2}\right)$. Monticellc et al. has reported that oxidiation of dibenzothiophene (DBT) which includes many sulfur containing polyaromatic hydrocarbons, is mediated by plasmid-borne functions in Pseudomonas isolates [73]. Two Pseudomonas species which oxidized DBT to water-soluble, sulfur-containing products harbored the 55-megadalton plasmid in contrast none of the $50 \mathrm{Dbt}^{-}$ colonies which are grown in medium supplemented with novobiocin $(30 \mathrm{ug} / \mathrm{ml})$ harbored a plasmid. Zillig et al. has reported that Sulfolobus ambivalens is able to live in an anaerobic mode of chemolithoautotrophy by using $\mathrm{Co}_{2}$ as carbon source and reduces sulfate to $\mathrm{H}_{2} \mathrm{~S}$ as an energy source [74]. They have correlated this mode of growth with amplification of a plasmid, pSL10. From a thermoacidophilic archaea S. islandicus, multicopy plasmids were isolated and a $5.3 \mathrm{~kb}$ plasmid. $\mathrm{pRNl}$, is completely sequenced which may be useful as cloning vectors in Sulfolobales [75]. A $14 \mathrm{~kb}$ plasmid isolated from green sulfur bacteria Chlorobium limicola f. sp. thiosulfatophilum is experimentally proved for carrying genes necessary for thiosulfate utilization or regulating such gene expression [76].
Hydrocarbon degradation: Biodegradation of hydrocarbon are of major concerned with environmental pollution and its harmful impact. Such harmful impact of hydrocarbon pollution are oil spillage, poly aromatic hydrocarbon pollution which are adsorbed to sediment and accumulated in aquatic animals like fish and shellfish followed by transfer to human through seafood consumption [77]. Microbial degradation of hydrocarbon is a useful technique of bioremediation without any adverse impact on environment. This property of microbes has evolved from a series of adaptation process in which they acquired few genes which are necessary to survive and propagate in a hydrocarbon reach environment. They require appropriate catabolic genes to be a good hydrocarbon degrader. Such special genes are often carried on plasmids of bacteria [78]. Plasmids which carry structural genes for organic matter or xenobiotic degradation are known as degradative or catabolic plasmids. It is experimentally proved that plasmids encode the enzymes required for metabolism of naphthalene, salicylate, camphor, octane, xylene, and toluene [79]. Hada and Sizemore had isolated 440 Vibrio from an operational oil field and control site located in the northwestern Gulf of Mexico [5]. They were screened for the presence of plasmids and $31 \%$ showed distinct plasmid bands on agarose gels with estimated molecular masses of $10 \times 10^{6}$ or less. The oil field area had noticeably more plasmid containing strains in comparison to control fields ( 35 versus $23 \%$ ) and number of plasmids per cell was more in bacteria isolated from polluted area (2.5 plasmids, versus 1.5 in the control site). This finding indirectly proves that plasmids are providing additional adaptability to microbes for organic compound degradation. Plasmids have a great role in PAH degradation and spreading this capacity among all other microbial community. For example naphthalene degradation capacity has experimentally marked to be transferred at low frequency by conjugation from strain NCIB 9816 into a plasmid-free strain of P. putida, PaW340 and the transconjugant, PaW701, containing the naphthalene plasmid pWW60-1, metabolize Naphthalene and salicylate by ortho pathway. Pseudomonas genes encode the upper and lower pathways of naphthalene degradation in the NAH plasmids which encodes for the enzymes that can metabolize a broad range of nutrition [80]. Yen and Serdar has explained how naphthalene is catabolized by Pseudomonas in a series of reactions to salicylic acid, which is further degraded to Krebs cycle intermediates [81]. The naphthalene catabolic genes have been located on self-transmissible plasmids and among them NAH7 is best studied. It consists of two operons involved in host utilization of naphthalene and salicylate as a carbon and energy source. Among all genes nahR codes for regulatory protein which is required to turn on the operon in presence of Salicylate as an inducer. These genes are highly unstable as it can undergo structural alteration by involving insertion or deletion during conjugation or altered nutritional condition. Li et al. for the first time reported complete naphthalene catabolic plasmid sequence of Pseudomonas sp. which consists of 101,858 bp nucleotide according to the whole-genome-shotgun approach. pND6-1 encodes 102 putative coding sequences (CDSs) [82]. Among them, 23 CDSs were predicted to be involved in naphthalene catabolism and rest of the CDSs indirectly helps in plasmid functioning. These all catabolic plasmids (pDTG1, NAH7 and pND6-1) have high sequence homology but they are highly versatile in their activity [83]. Other high molecular weight PAH degraders such as Mycobacterium sp are reported to degrade pyrene and they carry large plasmids but hybridization results shows that extrachromosomal DNA are not involved in degradation. Most of the pyrene degradative proteins are encoded by chromosomes. But in contrast Lin and Cai reported the isolation of plasmid from two strains, Bacillus cereus Py5 and Bacillus megaterium Py6 are involved in Pyrene degradation and after these plasmids transformed to E. coli, 
it was shown to degrade pyrene [84]. Plasmid pNL1 which is isolated from S. aromaticivorans F199 strain is suggested to be a broader host range plasmid, because it was transferred without any obvious structural changes to S. yanoikuyae B1, Sphingomonas sp. SS3, and $S$. herbicidovorans [85]. So it concludes that these broad host range plasmids are likely to spread PAH degradation capacity. Most of these degradative plasmids are evolved in a short time period by acquiring genes from bacterial chromosomes or self-alteration due to the external influence.

Drug resistance: Multiple drug resistance of bacteria is a major issue since early 1960s when there were many reports for antibiotic resistance of Shigellae in south east countries like Japan and Korea. This drug resistance has marked to be transferred to other Enterobacteriaceae by conjugation [86]. It is a major concern for all animals including aquatic organisms. Resistance to antibiotics is acquired from the factors called R-factors which are plasmids carrying resistant determinants (R-determinants) and resistance transfer factors (RTF). Anderson et al. has reported that these two components of R-plasmid are effective when present in a single cell. R-determinants are not transferable without RTF and alone RTF cannot develop drug resistant criteria [87]. The transfer of drug resistance is dependent on temperature and other physicochemical parameters of water. For example drug resistance of S. typhi isolated in Korea from 1968 to 1975 was more efficiently transferred to E. coli at $25^{\circ} \mathrm{C}$ than at $37^{\circ} \mathrm{C}$ [87]. Most of the drug resistance studies are aimed towards antibiotic resistance of human pathogenic bacteria for example Salmonella and shigellae. But it is also concerned with veterinary medicines which are indirectly transferred to human. The antibiotics which are resistant to bacteria are ampicillin (A), chloramphenicol $(\mathrm{C})$, neomycin $(\mathrm{N})$, kanamycin $(\mathrm{K})$, streptomycin (S), sulphonamides $(\mathrm{Su})$, and tetracycline $(\mathrm{T})$. Most of the R-factor elicits multiple drug resistance patterns for example $S$. typhimurium have common resistance patterns such as S T Su; A S T Su; and S T N $\mathrm{K} \mathrm{Su}$ [86]. These resistant pattern changes are due to incorporation of more drugs resistance. Disease occurrence in fish and shrimp culture system is increased due to the intensification of culture practice and in proportion to that antibiotic application has also increased. Due to improper and frequent application of antibiotic, tolerance level of pathogenic bacteria increases and the effective dose has to be increased or replaced with other drugs. In developed countries like the EU, the USA, Canada and Norway, there is strong regulation over use of certain antibiotics in aquaculture but in developing countries such regulation is still not implemented. Akinbowale et al. has reported about the antimicrobial resistance in Australian aquaculture system and briefly explained about drug resistance in aquaculture [88]. There are many reports of bacterial drug resistance in finfish culture farms as well as in shellfish hatcheries and ponds [89-92]. Antibiotic resistance is also observed in natural condition. It has been reported that frequency of pigmented bacteria and occurrence of bacterial antibiotic resistance were higher at the air-water interface than in the bulk water [93]. Sandaa and Enger has reported that in case of fishpathogenic bacterium Aeromonas salmonicida plasmid, pRAS1 encodes for tetracycline resistance is transferred at a high frequency in marine sediments even in the absence of a selective factor [94]. The presence of oxytetracycline increases transfer frequency to $3.4 \times 10^{-1}$ transconjugant per recipient and 3.6 transconjugants per donor cell. Keeping in view to the antibiotic resistance in shrimp aquaculture which is mostly exported food commodities, Coastal Aquaculture Authority (CAA) of India has banned twenty antibiotics and other pharmacologically active substances. Even in India Export Inspection Agency (EIA) never accept products with antibiotics and toxic chemical residues for export to other countries.

\section{List of chemicals banned for use in shrimp aquaculture (Coastal Aquaculture Authority of India)}

- Chloramphenicol.

- Nitrofurans including: Furaltadone, Furazolidone, Furylfuramide, Nifuratel, Nifuroxime, Nifurprazine, Nitrofurantoin, Nitrofurazone.

- Neomycin.

- Nalidixic acid.

- Sulphamethoxazole.

- Aristolochia spp and preparations thereof.

- Chloroform.

- Chlorpromazine.

- Colchicine.

- Dapsone.

- Dimetridazole.

- Metronidazole.

- Ronidazole.

- Ipronidazole.

- Other nitroimidazoles.

- Clenbuterol.

- Diethylstilbestrol (DES).

- Sulfonamide drugs (except approved Sulfadimethoxine, Sulfabromomethazine and Sulfaethoxypyridazine).

- Fluroquinolones.

- Glycopeptides.

\section{Conclusion}

Every animal has adaptation mechanism by which they survive on earth for a long period. For bacteria like prokaryotes, Plasmid is essential for adaptation by means of genetic diversity. Plasmids carry properties of xenobiotic degradation and heavy metal tolerance which makes them useful in bioremediation of toxic chemicals in ecofriendly manner. Whereas properties like antibiotic resistance is the consequence of indiscriminate use of drugs in culture system by farmers. The practice of genetic engineering of microbes and development of superior varieties is useful in comparison to chemical method of toxic remediation. A superior catalyst is made through combination of catabolic segments from different organisms within one recipient strain and such segments are frequently found in plasmids. Today we are using many plasmid vectors in gene cloning experiments but incorporation of antimicrobial resistance mediated selection method is harmful for ecosystem. It is important to investigate more regarding plasmids and their properties so that we will come to understand more about bacteria and their means of survival.

\section{Acknowledgement}

The authors are thankful to the Director, ICAR-Central Institute of Fisheries Education, Mumbai, India for his support in completing the manuscript.

\section{References}

1. Syavnen M (1994) Horizontal gene flow: Evidence and possible consequences Annu Rev Genet 28: 237-261. 
2. Syvanen M, Kado $\mathrm{Cl}$ (1998) Horizontal gene transfer. Chapman and Hall, London.

3. Tendencia EA, De La Pena LD (2001) Antibiotic resistant bacteria from shrimp ponds. Aquaculture 195: 193-204.

4. David CS (2005) Freshwater microbiology. In: Genetic interactions. John Wiley \& sons, LTD, Chichester, UK.

5. Hada HS, Sizemore RK (1981) Incidence of plasmids in marine Vibrio spp. isolated from an oil field in the northwestern Gulf of Mexico. Appl Environ Microbiol 41: 199-202.

6. Trevors JT, Barkey T, Bourquin AW (1987) Gene transfer among bacteria in soil and aquatic environments: A review. Can J Microbiol 33: 191-198.

7. Schutt C (1988) Plasmid-DNA in natural bacterial populations of four brownwater lakes (South Sweden). Arch Hydrobiol Beih 31: 133-139.

8. Chabbert YA, Scavizzi MR, Witchitz JL, Gerbaud GR, Bouanchaud DH (1972) Incompatibility groups and the classification of fire-resistance factors. $\mathrm{J}$ bacteriol 112: 666-675.

9. Richards H, Datta N (1979) Reclassification of incompatibility group L (IncL) plasmids. Plasmid 2: 293-295.

10. Sagai H, Hasuda K, lyobe S, Bryan LE, Holloway BW, et al. (1976) Classification of $\mathrm{R}$ plasmids by incompatibility in Pseudomonas aeruginosa. Antimicrob. Agents Chemother 10: 573-578.

11. Sasakawa C, Takamatsu N, Danbara H, Yoshikawa M (1980) A method of plasmid classification by integrative incompatibility. Plasmid 3: 116-127.

12. Couturier M, Bex F, Bergquist PL, Maas WK (1988) Identification and classification of bacterial plasmids. Microbiol rev 52: 375 .

13. Wang Z, Jin L, Yuan Z, Wegrzyn G, Wegrzyn A (2009) Classification of plasmid vectors using replication origin, selection marker and promoter as criteria. Plasmid 61: 47-51.

14. Lederberg J, Cavallli L, Lederberge M (1952) Sex compatibility in Escherichia coli. Genetics 37: 720.

15. Hayes W (1953) Observations on a transmissible agent determining sexual differentiation in Bacterium E. coli. J Gen Microbiol 8: 72.

16. Zverev VV, Kuzmin NP, Zuyeva LA, Burova El, Alexandrov AA, et al. (1984) Regions of homology in small colicinogenic plasmids. Plasmid 12: 203-205.

17. Chun D, Cho DT, Seol SY, Suh MH, Lee YC (1984) R plasmids conferring multiple drug resistance from shigella isolated in Korea. J Hyg 92: 153-160.

18. Demarre G, Guérout AM, Matsumoto-Mashimo C, Rowe-Magnus DA, Marlière $P$, et al. (2005) A new family of mobilizable suicide plasmids based on broad host range R388 plasmid (IncW) and RP4 plasmid (IncPa) conjugative machineries and their cognate Escherichia coli host strains. Res Microbiol 156: 245-255

19. Johnson J, Warren RL, Branstrom AA (1991) Effects of FP2 and a mercury resistance plasmid from Pseudomonas aeruginosa PA103 on exoenzyme production. J Clin Microbiol 29: 940-944.

20. Liosa M, Gomis-Rüth FX, Coll M, Cruz FDL (2002) Bacterial conjugation: A two-step mechanism for DNA transport. Mol Microbiol 45: 1-8.

21. Heinemann JA, Sprague GF (1989) Bacterial conjugative plasmids mobilize DNA transfer between bacteria and yeast. Nature 340: 205-209.

22. Waters VL (2001) Conjugation between bacterial and mammalian cells. Nature Genet 29: 375-376.

23. Sengeløv G, Sørensen SJ (1998) Methods for detection of conjugative plasmid transfer in aquatic environments. Curr Microbiol 37: 274-280.

24. Dahlberg C, Bergström M, Hermansson M (1998) In situ detection of high levels of horizontal plasmid transfer in marine bacterial communities. Appl Environ Microbiol 64: 2670-2675.

25. Jiang SC, Paul JH (1998) Gene transfer by transduction in the marine environment. Appl Env Microbiol 64: 2780-2787.

26. Morrison WD, Miller RV, Sayler GS (1978) Frequency of F116-mediated transduction of Pseudomonas aeruginosa in a freshwater environment. Appl Enviro Microbiol 36: 724-730

27. Ripp S, Ogunseitan OA, Miller RV (1994) Transduction of a freshwater microbial community by a new Pseudomonas aeruginosa generalized transducing phage, UT1. Mol Ecol 3: 121-126.

28. Lorenz MG, Wackernagel W (1994) Bacterial gene transfer by natural genetic transformation in the environment. Microbiol Rev 58: 563-602.

29. Lunsford RD (1998) Streptococcal transformation: Essential features and applications of a natural gene exchange system. Plasmid 39: 10-20.

30. Greaves MP, Wilson MJ (1970) The degradation of nucleic acids and montmorillonite-nucleic-acid complexes by soil microorganisms. Soil Biol Biochem 2: 257-268.

31. Maeda M, Taga N (1974) Occurrence and distribution of deoxyribonucleic acidhydrolyzing bacteria in sea water. J Exp Mar Biol Ecol 14: 157-169.

32. Paul JH, David AW (1989) Production of extracellular nucleic acids by genetically altered bacteria in aquatic-environment microcosms. Appl Environ Microbiol 55: 1865-1869.

33. Fernandez-Astorga A, Muela A, Cisterna R, Iriberri J, Barcina I (1992) Biotic and abiotic factors affecting plasmid transfer in Escherichia coli strains. Appl Environ Microbiol 58: 392-398.

34. Borsheim KY (1993) Native marine bacteriophages. FEMS Microbiol Lett 102 141-159.

35. Turk V, Rehnstam AS, Lundberg E, Hagström A (1992) Release of bacterial DNA by marine nano-flagellates, an intermediate step in phosphorus regeneration. Appl Environ Microbiol 58: 3744-3750.

36. Romanowski G, Lorenz MG, Wackernagel W (1993) Use of polymerase chain reaction and electroporation of Escherichia coli to monitor the persistence of extracellular plasmid DNA introduced into natural soils. Appl Environ Microbio 59: 3438-3446.

37. Romanowski G, Lorenz MG, Sayler G, Wackernagel W (1992) Persistence of free plasmid DNA in soil monitored by various methods, including a transformation assay. Appl Environ Microbiol 58: 3012-3019.

38. Bruns S, Reipschläger K, Lorenz MG, Wackernagel W (1992) Characterization of natural transformation of the soil bacteria Pseudomonas stutzeri and Acinetobacter calcoaceticus by chromosomal and plasmid DNA. Gene transfers and environment 115-126.

39. Frischer ME, Thurmond JM, Paul JH (1990) Natural plasmid transformation in a high-frequency-of-transformation marine Vibrio strain. Appl Environ Microbio 56: 3439-3444.

40. Lorenz MG, Wackernagel W (1990) Natural genetic transformation of Pseudomonas stutzeri by sand-adsorbed DNA. Arch Microbiol 154: 380-385.

41. Stewart GJ, Sinigalliano CD (1989) Detection and characterization of natura transformation in the marine bacterium Pseudomonas stutzeri strain ZoBell. Arch Microbiol 152: 520-526.

42. Paul JH, Frischer ME, Thurmond JM (1991) Gene transfer in marine wate column and sediment microcosms by natural plasmid transformation. App Environ Microbiol 57: 1509-1515.

43. Zhang R, Pan L, Zhao Z, Gu JD (2012) High incidence of plasmids in marine vibrio species isolated from Mai Po, Nature Reserve of Hong Kong Ecotoxicology 21: 1661-1668.

44. Baur B, Hanselmann K, Schlimme W, Jenni B (1996) Genetic transformation in freshwater: Escherichia coli is able to develop natural competence. App Environ Microbiol 62: 3673-3678.

45. Foster TJ (1983) Plasmid-determined resistance to antimicrobial drugs and toxic metal ions in bacteria. Microbiol Rev 47: 361

46. Summers AO, Silver S (1972) Mercury resistance in a plasmid-bearing strain of Escherichia coli. J Bacteriol 112: 1228-1236.

47. Silver S (1996) Bacterial resistances to toxic metal ions - A review. Gene 179: 9-19.

48. Tetaz TJ, Luke RK (1983) Plasmid-controlled resistance to copper in Escherichia coli. J Bacteriol 154: 1263-1268.

49. Cooksey DA (1987) Characterization of a copper resistance plasmid conserved in copper-resistant strains of Pseudomonas syringae pv. tomato. Appl Environ Microbiol 53: 454-456.

50. Cooksey DA (1994) Molecular mechanisms of copper resistance and accumulation in bacteria. FEMS Microbiol Rev 14: 381-386. 
51. Lee YA, Hendson M, Panopoulos NJ, Schroth MN (1994) Molecular cloning chromosomal mapping, and sequence analysis of copper resistance genes from Xanthomonas campestris pv. juglandis: homology with small blue coppe proteins and multicopper oxidase. J Bacteriol 176: 173-188.

52. Nucifora G, Chu L, Misra TK, Silver S (1989) Cadmium resistance from Staphylococcus aureus plasmid pl258 cadA gene results from a cadmiumefflux ATPase. Proc Natl Acad Sci 86: 3544-3548.

53. Vutukuru SS (2005) Acute effects of hexavalent chromium on survival, oxygen consumption, hematological parameters and some biochemical profiles of the Indian major carp, Labeo rohita. Int J Environ Res Publ Health 2: 456-462.

54. Dhakephalkar PK, Bhide JV, Paknikar KM (1996) Plasmid mediated chromate resistance and reduction in Pseudomonas mendocina MCM B-180. Biotechnol Lett 18: 1119-1122.

55. Bopp LH, Chakrabarty AM, Ehrlich HL (1983) Chromate resistance plasmid in Pseudomonas fluorescens. J Bacteriol 155: 1105-1109.

56. Nebeker AV, McAuliffe CK, Mshar R, Stevens DG (1983) Toxicity of silver to steelhead and rainbow trout, fathead minnows and Daphnia magna. Environ Toxicol Chem 2: 95-104.

57. McHugh SL (1975) Salmonella typhimurium resistant to silver nitrate chloramphenicol, and ampicillin. Lancet I 235: 240.

58. Diels L, Sadouk A, Mergeay M (1989) Large plasmids governing multiple resistances to heavy metals: A genetic approach. Toxicol Environ Chem 23: $79-89$

59. Ji G, Silver S (1995) Bacterial resistance mechanisms for heavy metals of environmental concern. J Ind Microbiol 14: 61-75.

60. Lebrun M, Audurier A, Cossart P (1994) Plasmid-borne cadmium resistance genes in Listeria monocytogenes are similar to cadA and cadC of Staphylococcus aureus and are induced by cadmium. J Bacteriol 176: 3040-3048.

61. Ohtake H, Cervantes C, Silver S (1987) Decreased chromate uptake in Pseudomonas fluorescens carrying a chromate resistance plasmid. J Bacteriol 169: 3853-3856.

62. Summers AO, Jacoby GA (1978) Plasmid-determined resistance to boron and chromium compounds in Pseudomonas aeruginosa. Antimicrobial agents and chemotherapy 13: 637-640.

63. Walter EG, Taylor DE (1989) Comparison of tellurite resistance determinants from the IncP alpha plasmid RP4Ter and the IncHII plasmid pHH1508a. J Bacteriol 171: 2160-2165.

64. Taylor DE, Walter EG, Sherburne R, Bazett-Jones DP (1988) Structure and location of tellurium deposited in Escherichia coli cells harboring tellurite resistance plasmids. J Ultrastruct Mol Struct 99: 18-26.

65. Van Den Hondel CAMJJ, Keegstra W, Borrias WE, Van Arkel GA (1979) Homology of plasmids in strains of unicellular cyanobacteria. Plasmid 2 323-333.

66. Felkner RH, Barnum SR (1988) Plasmid content and homology of 16 strains of filamentous, non-heterocystous cyanobacteria. Curr Microbiol 17: 37-41.

67. Nuti MP, Lepidi AA, Prakash RK, Schilperoort RA, Cannon FC (1979) Evidence for nitrogen fixation (nif) genes on indigenous Rhizobium plasmids. Nature 282: $533-535$.

68. Ruvkun GB, Ausubel FM (1980) Interspecies homology of nitrogenase genes. Proc Natl Acad Sci 77: 191-195.

69. Krol AJM, Hontelez JGJ, Van Den Bos RC, Van Kammen A (1980) Expression of large plasmids in the endosymbiotic form of Rhizobium leguminosarum. Nucleic Acids Res 8: 4337-4348.

70. Bishop PE, Dazzo FB, Appelbaum ER, Maier RJ, Brill WJ (1977) Intergeneric transfer of genes involved in the Rhizobium-legume symbiosis. Science 198: 938-940.

71. Riedel GE, Brown SE, Ausubel FM (1983) Nitrogen fixation by Klebsiella pneumoniae is inhibited by certain multicopy hybrid nif plasmids. J Bacteriol 153: $45-56$.

72. Masterson RV, Russell PR, Atherly AG (1982) Nitrogen fixation (nif) genes and large plasmids of Rhizobium japonicum. J Bacteriol 152: 928-931.

73. Monticello DJ, Bakker D, Finnerty WR (1985) Plasmid-mediated degradation of dibenzothiophene by Pseudomonas species. Appl Environ Microbiol 49 . 756-760.

74. Zillig W, Yeats S, Holz I, Böck A, Gropp F, et al. (1984) Plasmid-related anaerobic autotrophy of the novel archaebacterium Sulfolobus ambivalens. Nature 313: 789-791.

75. Keeling PJ, Klenk HP, Singh RK, Feeley O, Schleper C, et al. (1996) Complete nucleotide sequence of the Sulfolobus islandicus multicopy plasmid pRN1. Plasmid 35: 141-144.

76. Mendez-Alvarez S, Pavón V, Esteve I, Guerrero R, Gaju N (1994) Transformation of Chlorobium limicola by a plasmid that confers the ability to utilize thiosulfate. J Bacteriol 176: 7395-7397.

77. Meador JP, Stein JE, Reichert WL, Varanasi U (1995) Bioaccumulation of polycyclic aromatic hydrocarbons by marine organisms. In Rev environ contamt, Springer New York.

78. Johnsen AR, Wick LY, Harms H (2005) Principles of microbial PAH-degradation in soil. Environ Pollut 133: 71-84.

79. Chakrabarty AM (1976) Plasmids in Pseudomonas. Annu Rev Genet 10: 7-30.

80. Foght JM, Westlake DW (1996) Transposon and spontaneous deletion mutants of plasmid-borne genes encoding polycyclic aromatic hydrocarbon degradation by a strain of Pseudomonas fluorescens. Biodegradation 7: 353-366.

81. Yen KM, Serdar CM (1988) Genetics of naphthalene catabolism in Pseudomonas. Crit Rev Microbiol 15: 247-267.

82. Li W, Shi J, Wang X, Han Y, Tong W, et al. (2004) Complete nucleotide sequence and organization of the naphthalene catabolic plasmid pND6-1 from Pseudomonas sp. strain ND6. Gene 336: 231-240.

83. Obayori OS, Salam LB (2010) Degradation of polycyclic aromatic hydrocarbons: Role of plasmids. Sci Res Essays 5: 4093-4106.

84. Lin Y, Cai LX (2008) PAH-degrading microbial consortium and its pyrenedegrading plasmids from mangrove sediment samples in Huian, China. Marine Poll Bull 57: 703-706.

85. Basta T, Keck A, Klein J, Stolz A (2004) Detection and characterization of conjugative degradative plasmids in xenobiotic-degrading Sphingomonas strains. J Bacteriol 186: 3862-3872.

86. Anderson ES (1965) Origin of transferable drug-resistance factors in the enterobacteriaceae. Br Med J 2: 1289-1291.

87. Chun D, Seol SY, Cho DT, Tak R (1977) Drug resistance and R plasmids in Salmonella typhi isolated in Korea. Antimicrob Chemo 11: 209-213.

88. Akinbowale OL, Peng H, Barton MD (2006) Antimicrobial resistance in bacteria isolated from aquaculture sources in Australia. J Appl Microbiol 100: 1103 1113.

89. Tjahjadi MR, Angka SL, Suwanto A (1994) Isolation and evaluation of marine bacteria for biocontrol of luminous bacterial disease in tiger shrimp larvae (Penaeus monodon, Fab.). Asia Pac J Mol Biol Biotechnol 2: 347-352.

90. Ho SP, Hsu TY, Chen MH, Wang WS (2000) Antibacterial effect of chloramphenicol, thiamphenicol and florfenicol against aquatic animal bacteria J Vet Med Sci 62: 479-485.

91. Hossain MS, Aktaruzzaman M, Fakhruddin ANM, Uddin MJ, Rahman SH, et al. (2012) Prevalence of multiple drug resistant pathogenic bacteria in cultured black tiger shrimp (Penaeus monodon fabricius). Global J Environ Res 6: 118-124.

92. Manjusha S, Sarita GB (2013) Characterization of plasmids from multiple antibiotic resistant Vibrios isolated from molluscan and crustacean of Kerala. Int Food Res J 40: 197-207.

93. Hermansson M, Jones GW, Kjelleberg S (1987) Frequency of antibiotic and heavy metal resistance, pigmentation, and plasmids in bacteria of the marine air-water interface. Appl Environ Microbiol 53: 2338-2342.

94. Sandaa RA, Enger O (1994) Transfer in marine sediments of the naturally occurring plasmid pRASi encoding multiple antibiotic resistance. Appl Environ Microbiol 60: 4234-4238. 